\title{
Membrane Biophysics and Mechanics in Alzheimer's Disease
}

\author{
Xiaoguang Yang • Sholpan Askarova • James C-M. Lee
}

Received: 22 December 2009/Accepted: 17 March 2010/Published online: 1 May 2010

(C) Springer Science+Business Media, LLC 2010

\begin{abstract}
Alzheimer's disease is a chronic neurodegenerative disorder characterized by neuronal loss, cerebrovascular inflammation, and accumulation of senile plaques in the brain parenchyma and cerebral blood vessels. Amyloid- $\beta$ peptide $(\mathrm{A} \beta)$, a major component of senile plaques, has been shown to exert multiple toxic effects to neurons, astrocytes, glial cells, and brain endothelium. Oligomeric $\mathrm{A} \beta$ can disturb the structure and function of cell membranes and alter membrane mechanical properties, such as membrane fluidity and molecular order. Much of these effects are attributed to their capability to trigger oxidative stress and inflammation. In this review, we discuss the effects of $A \beta$ on neuronal cells, astrocytes, and cerebral endothelial cells with special emphasis on cell membrane properties and cell functions.
\end{abstract}

Keywords Amyloid- $\beta$ - Alzheimer's disease .

Membrane properties $\cdot$ Membrane order .

Membrane fluidity $\cdot$ Membrane potential .

Cerebral endothelium

\section{Introduction}

Alzheimer's disease (AD) is a progressive neurodegenerative disorder, which affects higher cognitive functions,

Xiaoguang Yang and Sholpan Askarova contributed equally to the work.

X. Yang $\cdot$ S. Askarova · J. C.-M. Lee $(\bowtie)$

Department of Biological Engineering, University of Missouri,

240 Agricultural Engineering Building,

Columbia, MO 65211, USA

e-mail: leejam@missouri.edu memory, and learning. In AD brains, there is an increased deposition of amyloid plaques together with the increased number of activated microglial cells in the parenchyma and monocytes in the vessel wall [1-6]. Amyloid- $\beta$ peptide $(A \beta)$ derived from the amyloidogenic pathway of amyloid precursor protein (APP) processing [7] is the primary component of amyloid plaques [8]. A $\beta$ monomers aggregate into oligomers, fibrils, and plaques, which have different impacts on cellular functions [9-13]. In fact, it has been reported that oligomeric $A \beta$ is more toxic than fibrillar and monomeric $A \beta$ [11]. Deposition of $A \beta$ in $A D$ brains and cerebral vessels results in neurovascular dysfunction and chronic neurodegeneration [14]. In addition, oligomeric $A \beta$ can induce oxidative stress, apoptosis, abnormal calcium homeostasis, and long-term potentiation and can self-assemble into large, voltage-independent, and nonselective ion channels at cell membranes. $A \beta$ can also perturb the molecular packing of cell membranes, resulting in subsequent alterations of biophysical properties of membranes, such as membrane microviscosity, membrane molecular order, membrane potential, and permeability. Altered membrane properties, in turn, may disrupt membrane functions, activities of membrane-related proteins, and many cellular pathways. Understanding the mechanisms leading to changes of membranes mechanics and biophysics and how they result in changes in cell functions should prove to provide insights into new therapeutic strategies for prevention and treatment of $\mathrm{AD}$.

\section{A $\beta$-Membrane Interactions in Neurons}

The accumulation of $A \beta$ to form senile plaques is one of the hallmarks of $\mathrm{AD}$. Interactions between $\mathrm{A} \beta$ peptides and neuronal membranes play a vital role in the neurotoxicity associated with $\mathrm{AD}$ [15-23]. By virtue of its structure, $A \beta$ 
is capable of binding to a variety of biomolecules including lipids and proteins, which, in turn, perturbs the organization and functions of membranes, such as membrane fluidity and the formation of ion channel and neurotoxicity [24, 25]. There are two types of $A \beta$-membrane interactions: $A \beta$ peptide can either be firmly anchored in a membrane upon proteolytic cleavage, thereby being prevented against release and aggregation, or it can have adverse effects when bound to membrane surfaces by undergoing accelerated aggregation and causing neuronal apoptotic cell death [21]. On the other hand, membrane charge and membrane fluidity can influence the conformational structure of $\mathrm{A} \beta, \mathrm{A} \beta$ binding, and permeabilization [26]. For example, when $A \beta$ is exposed to small amounts of sodium dodecyl sulfate (SDS), which mimic the negatively charged membrane environment, it is converted to $\beta$-sheet [23].

$\mathrm{A} \beta$ binding to plasma membranes can cause the disturbance of the structure and function of membranes. Williamson et al. [22] showed that exogenously applied $A \beta$ was redistributed on membrane and accumulated in lipid rafts where the protein composition was altered. After $A \beta$ treatment, neuronal membranes are depolarized [27] and exhibit changes in varicosities along neurites and enhance membrane permeability to propidium iodide [28]. In addition, using mass spectrometric assay of lipid damage, Murray et al. [29] showed that oxidative lipid damage caused by A $\beta$ was accelerated in the presences of ascorbate and copper ion.

In addition to plasma membrane damage, $A \beta$ can cause intracellular membrane damage. For example, disturbances of endosomal/lysosomal system are implicated in the process of neurodegeneration [30]. $\mathrm{A} \beta$ in the culture medium can be taken up by neurons and accumulate inside the endosomal/lysosomal system. Exposing cultured neurons to soluble $A \beta$ can trigger free radical generation within lysosomes and disruption of lysosomal membrane proton gradient and lead to the loss of lysosomal membrane impermeability preceding to cell death [16].

\section{Cholesterol Modulates $A \beta-$ Membrane Interactions}

Cholesterol plays an important role in the pathogenesis of $\mathrm{AD}$ [31-36]. It has been shown that cholesterol can modulate the interactions between $\mathrm{A} \beta$ and membrane [37] and that membrane insertion ability of $A \beta$ is critically controlled by the ratio of cholesterol to phospholipids. In membranes with low concentrations of cholesterol, $A \beta$ prefers to stay within the membrane surface region and is mainly in the $\beta$-sheet structure. In contrast, as the ratio of cholesterol to phospholipids rises, $A \beta$ can insert spontaneously into the lipid bilayer due to its hydrophobic C-terminus [38].

In addition, membrane cholesterol can modulate the cleavage of amyloid precursor protein (APP) and alter the production of $A \beta[33,36,39]$. In fact, it has been reported that membrane cholesterol depletion decreases the content of APP in cholesterol and sphingolipid-enriched membrane microdomains and subsequently inhibits the amyloidogenic pathway to produce $A \beta$. Moreover, depletion of cellular cholesterol levels reduces the ability of $A \beta$ to act as a seed for further fibril formation $[34,35]$. There is evidence that plasma membrane cholesterol controls the toxicity of $A \beta$ [40] and protects cells from apoptosis induced by soluble oligomers but not fibrils of $\mathrm{A} \beta$ [41]. There are some contradictory results from different studies [42-44], possibly due to using different models and experimental conditions. Consequently, more systematic studies are needed to address the discrepancy.

\section{$\mathrm{A} \beta$ Induces Membrane Damage and Dysregulation} of Calcium Concentration

Dysregulation of ion homeostasis has been implicated in the pathogenesis of AD. Dysregulated inositol triphosphate (IP3) signaling in cortical neurons of knock-in mice expressing an Alzheimer's-linked mutation in presenilin1 results in exaggerated $\mathrm{Ca}^{2+}$ signals and altered membrane excitability [45]. Protein kinase $\mathrm{C}$ inhibits the transplasma membrane influx of $\mathrm{Ca}^{2+}$ triggered by 4-aminopyridine in Jurkat T lymphocytes [46]. Apolipoprotein E epsilon 4 allele (apoE4) has a clear association with AD. ApoE4 molecules can rapidly suppress the activities of delayed rectifier potassium (IK) channels in hippocampal neurons when they are applied on the inner side of the neuronal membrane [47]. Overproduction of apoE4 in neurons may suppress normal IK channel activities and thus be responsible for the neuronal damages related to the pathogenesis of $\mathrm{AD}$.

$\mathrm{A} \beta$ has been shown to form $\mathrm{Ca}^{2+}$ channels in lipid vesicles and alter the concentration of intracellular $\mathrm{Ca}^{2+}$ in neuronal cells and astrocytes [48-55]. A $\beta$ decreases plasma membrane $\mathrm{Ca}^{2+}$-ATPase (PMCA) activity purified from normal brain, which plays a crucial role in controlling cytosolic $\mathrm{Ca}^{2+}[56]$. $\mathrm{A} \beta$ also invoked the release of calcium from the endoplasmic reticulum (ER) and subsequently triggered apoptotic pathway $[11,57,58]$. In turn, calcium signaling increased the aggregation of early protofibrillar structures and markedly increased conversion of protofibrils to mature amyloid fibrils, which play a role in the pathogenesis of $\mathrm{AD}[59]$.

Phospholiases $\mathrm{A}_{2}$ and Cell Membrane Properties in $\mathrm{AD}$

$\mathrm{A} \beta$ deposits are associated with the activation of phospholipase $\mathrm{A}_{2}\left(\mathrm{PLA}_{2} \mathrm{~s}\right)$ [60-62]. These enzymes are ubiquitous in mammalian cells for catalyzing the cleavage of fatty acids from $s n-2$ position of phospholipids. $\mathrm{PLA}_{2} \mathrm{~S}$ are 
classified into three major families: calcium-dependent cytosolic $\mathrm{PLA}_{2}\left(\mathrm{cPLA}_{2}\right)$, secretory $\mathrm{PLA}_{2}\left(\mathrm{sPLA}_{2}\right)$, and calcium-independent $\mathrm{PLA}_{2}\left(\mathrm{PPLA}_{2}\right)$. These enzymes are responsible for maintenance of phospholipid homeostasis in cell membranes. They are also important in the production of lipid mediators, such as arachidonic acid (AA), a precursor for synthesis of eicosanoids [63, 64]. Activation of $\mathrm{PLA}_{2} \mathrm{~S}$ occurs in a number of pathologic conditions including $\mathrm{AD}$ [63-72].

It has been reported that immunoreactivity of $\mathrm{CPLA}_{2}$ (group IVA) increased in reactive astrocytes in severe $\mathrm{AD}$ patient brains $[60,61]$. In addition, increases in immunoreactivity of SPLA $_{2}$-IIA in astrocytes were found in postmortem inferior temporal gyrus and hippocampal dentate gyrus and $\mathrm{CA} 3$ field of $\mathrm{AD}$ brains [62]. Upregulation of SPLA $_{2}$-IIA mRNA was reported in the hippocampus (confined mainly to dentate gyrus and CA3 field) of $\mathrm{AD}$ patients [62]. cPLA $_{2}$ mRNA was also upregulated in the hippocampal $\mathrm{CA} 1$ field of $\mathrm{AD}$ patients [73]. Furthermore, $A \beta$ has been shown to activate $\mathrm{CPLA}_{2}$ in primary rat or mouse cortical neurons and in $\mathrm{PC} 12$ cells [74-77].

$\mathrm{PLA}_{2}$ plays key roles in modulation of membrane properties under pathologic and physiologic conditions. For instance, the treatment of immortalized astrocytes (DITNC) with $A \beta$ promotes the reactive oxygen species (ROS) production from nicotinamide adenine dinucleotide phosphate (NADPH) oxidase and activation of $\mathrm{CPLA}_{2}$, which, in turn, increased membrane molecular order [78]. Membrane microdomains, which are enriched in cholesterol, sphingolipids, and saturated phospholipids, are highly ordered and tightly packed $[79,80]$. There is less water content in these membrane microdomains. The emission spectrum of LAURDAN, an environment sensitive probe, is sensitive to membrane phase properties (e.g., molecular order). The generalized polarization (GP) of LAURDAN has been defined to characterize the change of the emission spectrum due to changes in membrane phase properties [81-86]. Methylarachidonyl fluorophosphonate, the inhibitor of $\mathrm{CPLA}_{2}$ and $\mathrm{PLA}_{2}$, suppressed the increase in membrane order, but bromoenol lactone (BEL), the specific inhibitor of $\mathrm{iPLA}_{2}$, did not. These results suggest that cPLA $_{2}$ but not iPLA ${ }_{2}$ mediated the $A \beta$-induced membrane molecular order increase [78]. In primary rat cortical astrocytes, ROS induced by menadione, a redox active agent, also alters astrocyte membrane molecular order through activation of $\mathrm{cPLA}_{2}$ [87].

Membrane fluidity is another important parameter for characterizing the physiologic state of the cells. In AD brains, there is evidence for reduced membrane fluidity together with the decreased $\mathrm{PLA}_{2}$ activity [88-90]. Other studies also show that inhibition of $\mathrm{PLA}_{2}$ reduces membrane fluidity $[91,92]$. Injection of $\mathrm{PLA}_{2}$ inhibitor into the
CA1 area of rat hippocampus resulted in reduced membrane fluidity as compared with control [91, 92]. In addition, inhibition of $\mathrm{PLA}_{2}$ activity also impaired the formation of short- and long-term memory [91, 92]. This finding is interesting and may have important implications in potential therapy for $\mathrm{AD}$.

\section{Mitochondrial Dysfunction in AD}

Several lines of evidence suggest that mitochondrial dysfunction plays an important role in $\mathrm{AD}$ pathogenesis. Studies of postmortem brains indicated that neurons from $\mathrm{AD}$ brains were deficient in pyruvate dehydrogenase and cytochrome oxidase activity [93]. Mitochondrial encoded gene expressions were aberrant in $\mathrm{AD}$ postmortem brains and transgenic mice overexpressing human mutant APP $[94,95]$. Several other studies showed decreased ATP production and increased production of free radicals, lipid peroxidation, oxidative DNAs, and protein damages in $\mathrm{AD}$ brains [96-99]. Several groups found that $A \beta$ can accumulate in mitochondrial membrane and subsequently induce mitochondrial dysfunction and ROS production [100-103]. The result from rat mitochondria showed that $A \beta$ is transported into mitochondria via the translocase of the outer membrane (TOM) machinery, and after the import, $A \beta$ is associated with the inner membrane fraction [102]. $A \beta$ progressively accumulates in mitochondria and is associated with the decreased enzymatic activity of respiratory chain complexes (III and IV) and the reduction in the rate of oxygen consumption and increased ROS production $[100,103]$. Importantly, mitochondria-associated $A \beta$ was detected as early as 4 months, before extensive extracellular A $\beta$ deposits in APP transgenic mice [100]. These studies delineate a new means, through which $A \beta$ potentially impairs neuronal energetics, contributing to cellular dysfunction in $\operatorname{AD}[100,103]$. Although the mechanism is still not fully understood, $A \beta$-induced mitochondrial dysfunction is also associated with abnormal mitochondrial dynamics [104].

$\mathrm{A} \beta$-induced activation of $\mathrm{PLA}_{2}$ may play a role in mitochondrial dysfunction. In fact, our studies demonstrated that the $\mathrm{A} \beta$-induced activation of $\mathrm{PLA}_{2}$ led to loss of mitochondrial membrane potential $\left(\Delta \Psi_{\mathrm{m}}\right)$ and mitochondrial ROS production in primary rat cortical astrocytes [105]. In this study, oligomeric $A \beta$ was shown to activate $\mathrm{cPLA}_{2}$ through the NADPH oxidase and mitogen-activated protein kinase pathway as well as methylarachidonyl fluorophosphonate, inhibitor of both $\mathrm{CPLA}_{2}$ and $\mathrm{PPLA}_{2}$, completely suppressed loss of $\mathrm{A} \beta$-induced $\Delta \Psi_{\mathrm{m}}$, indicating that activation of $\mathrm{PLA}_{2}$ is required for the $\Delta \Psi_{\mathrm{m}}$ loss in astroctyes [105]. On the other hand, BEL, a specific inhibitor of $\mathrm{iPLA}_{2}$, can only suppress A $\beta$-induced $\Delta \Psi_{\mathrm{m}}$ loss during the first 12 to 15 minutes, suggesting that PLA $_{2}$ 
is involved in the initial $\Delta \Psi_{\mathrm{m}}$ loss [105]. Since BEL is specific for iPLA $\mathrm{P}_{2}$ inhibition, these results suggest that a lag time of about 12 to 15 minutes was required for $\mathrm{CPLA}_{2}$ to induce $\Delta \Psi_{\mathrm{m}}$ loss. Consistently, confocal fluorescence microscopy analysis demonstrated increase in colocalization between $\mathrm{p}-\mathrm{cPLA}_{2}$ and mitochondria 20 minutes after $A \beta$ treatment [105]. Taken together, these data suggest a mechanism for $A \beta$-induced initial ROS production through $\mathrm{NADPH}$ oxidase, which leads to activation of $\mathrm{PLA}_{2}$, and activated $\mathrm{CPLA}_{2}$ and $\mathrm{PLA}_{2}$ in turn target mitochondria and subsequently cause the $\Delta \Psi_{\mathrm{m}}$ loss and mitochondrial ROS production.

Since $\mathrm{PLA}_{2}$ is responsible for hydrolysis of membrane phospholipids and for the release of free fatty acids and lysophospholipids, enhanced $\mathrm{PLA}_{2}$ activity may have a number of physiologic consequences. Free fatty acids are classical uncouplers of mitochondrial respiratory chain [106, 107], and lysophospholipids possess detergent properties. AA release by $\mathrm{PLA}_{2}$ has been shown to trigger a $\mathrm{Ca}^{2+}$-dependent apoptotic pathway by opening mitochondrial permeability transition pores (mPTP) [108]. However, the mechanisms linking $\mathrm{A} \beta, \mathrm{PLA}_{2}$, and mitochondrial dysfunctional are still poorly understood and require additional studies.

\section{Membrane Biophysics and APP Processing}

$A \beta$ is derived from cleavage of amyloid precursor protein (APP) by $\beta$ - and $\gamma$-secretases [7]. Alternatively, APP can be cleaved by $\alpha$-secretase and produce neurotrophic and neuroprotective soluble APP $\left(\mathrm{sAPP}_{\alpha}\right)$ in a nonamyloidogenic pathway [109]. Since APP and $\alpha-, \beta-$, and $\gamma-$ secretases are membrane proteins, APP processing can be affected by the local membrane environment. The cleavage of APP by $\beta$-secretase (BACE), the primary step to produce $A \beta[110,111]$, occurs mainly in lipid rafts, which are highly ordered membrane microdomains enriched with cholesterol, sphingolipids, and saturated phospholipids [112-117]. On the other hand, the activity of $\alpha$-secretases is favorable in nonraft domains [31]. Therefore, APP processing can be altered by manipulating membrane lipid composition, such as removal of cholesterol and sphingolipids [36, 118-120]. Since $\mathrm{PLA}_{2}$ can alter membrane properties, it is reasonable that these enzymes can also affect APP processing and increase $\mathrm{sAPP}_{\alpha}$ production [121]. In our recent study, we demonstrated the capability of $\mathrm{sPLA}_{2}$-III and AA to increase $\mathrm{SAPP}_{\alpha}$ secretion and alter membrane fluidity in neuronal cells [122]. In another study, $\mathrm{sPLA}_{2}$-III was shown to increase membrane fluidity in hippocampal neurons in vivo [123]. Besides AA, docosahexenoic acid (DHA) can also increase membrane fluidity and $\mathrm{SAPP}_{\alpha}$ secretion in human embryonic kidney 293 cells (HEK) cells and in neuronal SH-SY5Y overexpressing APP cells [124]. Other studies demonstrated effects of benzyl alcohol $\left(\mathrm{C}_{6} \mathrm{H}_{5} \mathrm{OH}\right)$ to increase membrane fluidity and sAPP $_{\alpha}$ secretion, whereas Pluronic F68 (PF68) decreased membrane fluidity and $\mathrm{sAPP}_{\alpha}$ secretion [125]. In turn, $\mathrm{A} \beta$ itself accelerates the amyloidogenic processing of APP by reducing membrane fluidity [125]. These results suggest that compounds capable of altering membrane fluidity can modulate $\operatorname{SAPP}_{\alpha}$ production. Study by Kojro et al. [36] showed that treatment with methyl- $\beta$-cyclodextrin $(\mathrm{M} \beta \mathrm{CD})$ to reduce cellular cholesterol increased membrane fluidity, APP accumulation at the cell surface, and $\operatorname{sAPP}_{\alpha}$ secretion. Our study also showed that $\mathrm{SPLA}_{2}$-III and AA treatment increased the accumulation of APP at cell surface [122]. These results are consistent with the notion that $A \beta$ production mainly occurs in endosomes [120, 126-130].

Taken together, increase in membrane fluidity seems to result in APP accumulation at the cell surface and increase in $\operatorname{sAPP}_{\alpha}$ secretion. Since $\operatorname{sAPP}_{\alpha}$ is neuroprotective and neurotrophic, and $\alpha$-secretase cleavage of APP may compete with the BACE cleavage, enhancing the nonamyloidogenic pathway should prove to be a potential pharmacologic approach for the treatment of $\mathrm{AD}$.

\section{Effects of $A \beta$ on Cerebral Endothelium}

Cerebral endothelial cell (CECs) layer is a major component of the blood-brain barrier (BBB). CECs layer is consisted of high-density cells connected by tight junctions. CECs have a little number of endothelial pores, are rich in mitochondria, and have a very low content of the pinocytotic vesicles. The biomechanical properties of the CECs are critical to regulations of many cellular functions, such as adhesion, signaling, and morphology and play a vital role in the maintenance of the BBB permeability and brain parenchyma homeostasis.

In agreement with impairments of CECs structure and functions in $\mathrm{AD}$, many studies have indicated the decrease in cerebral blood flow, reduced microvascular density, and low immunoreactivity of endothelial markers CD34 and CD31 in AD brains [131-136]. Light and electron microscopy studies have demonstrated decreased mitochondrial and increased pinocytotic vesicles content, swelling, and degeneration of endothelial cells in $\mathrm{AD}$ brain $[137,138]$. In vitro studies have also shown the ability for $A \beta$ to induce significant dysfunctions in the CECs. Specifically, physiologic concentrations of soluble $A \beta\left(10^{-9}-10^{-6} \mathrm{M}\right)$ induced dose-dependent reduction of NO production, altered cellular calcium level by forming calcium-permeable channels in the membranes, initiated albumin transfer across EC monolayer, and impaired EC glucose uptake [139-142]. Higher concentrations of $\mathrm{A} \beta$ have been demonstrated to induce mitochondria dysfunction, nuclear chromatin condensation, DNA fragmentation, and significant CECs death $[140,141,143]$. 
There is increasing evidence that oxidative stress is a major mechanism leading to a cerebrovascular dysfunction in AD. Several studies of transgenic mice overexpressing APP have demonstrated oxidative damage of CECs, upregulation of superoxide dismutase (SOD) around brain microvessels, and significant impairment of the cerebrovascular functions [144-146]. In vitro, the treatment of CECs with $A \beta$ increased free radical production, and this effect was attenuated by free radical scavengers [144]. A $\beta$ induced oxidative stress in CECs, in turn, initiated a cascade of redox reactions leading to apoptosis and neurovascular inflammation [141, 143, 147-150]. ROS also cause CECs membrane depolarization, dysfunction of membrane binding proteins, and alteration of membrane structure and functions [151-154].

In $\mathrm{AD}$ brains, the increased deposition of $\mathrm{A} \beta$ in the cerebral vasculature has been found to correlate with the accumulation of monocytes in the vessel walls and activated microglia cells in the adjacent parenchyma [155-157]. There is evidence that peripheral monocytes can migrate across the BBB and differentiate into microglia [158]. In vitro studies have demonstrated that $A \beta$ deposition at the endothelial cell layer enhances the transmigration of monocytes [159-162]. Since primary capture of the monocytes to endothelium and rolling are mediated by tethering on selectin-ligand interactions [163-165], mechanical properties of the membranes and membranecytoskeleton connectivity as well as the expression of adhesion molecules are critical for transmigration [166171]. To study the direct effects of oligomeric $A \beta$ on mechanical properties of CECs, atomic force microscopy (AFM) and quantitative fluorescent microscopy (QIM) were applied (Askarova et al., unpublished data). QIM studies have demonstrated that $\mathrm{A} \beta$ promoted expression of adhesion molecules (P-selectin) and increased actin polymerization. Consistent with QIM results, AFM data demonstrated that oligomeric $A \beta$ increased cell stiffness and the probability of adhesion, but decreased the apparent rupture force of selectin-ligand bonding, probably due to dissociation of connectivity between the cytoskeleton and the bilayer membrane (Askarova et al., unpublished data).

The tight junctions of high electrical resistance and close cell-cell contacts are also critical biomechanical factors maintaining brain homeostasis and impermeability of BBB for the blood cells. Tight junction is a complex of transmembrane proteins (occluding, claudins, junctional molecule-1) and submembrane molecules connected to actin network. In vitro studies have demonstrated that exposure of CECs to $A \beta$ altered expression of occluding and claudin-1, disrupted plasma membrane subunits of claudin-5, and led to relocation of the submembrane protein ZO-2 to the cytoplasm [172]. Several studies have shown that oligomeric $A \beta$ also altered actin polymerization within neurons and CECs $[173,174]$. These findings suggest that the effects of $A \beta$ on actin and tight junction protein complexes may cause the alteration of endothelial layer integrity and contribute to the enhanced transmigration of monocytes across the BBB.

Consequently, chronic neurovascular dysfunctions and degeneration of endothelium are observed in all stages of $\mathrm{AD}$ and may even precede neuron degeneration in $\mathrm{AD}$ brains $[175,176]$. In vivo and In vitro studies have demonstrated that vascular deposition of $A \beta$ induces oxidative stress in cerebral vasculature, triggers inflammatory processes and apoptosis, promotes expression of adhesion molecules, affects tight junctions, and changes mechanical properties of the CECs membranes in a manner favoring transmigration of immune cells across BBB. Continuous degeneration of CECs is likely to impair BBB permeability, leading to leakage of blood plasma components and neurotoxic substances into the brain parenchyma. Breakdown of BBB functions drives the disease development toward exacerbation of oxidative and inflammatory conditions characteristic of the $\mathrm{AD}$ brain and contributes to further progression of the disease. Understanding the early molecular and biophysical mechanisms of the CECs alteration may offer new approaches to diagnosis and treatment of $\mathrm{AD}$.

\section{Conclusion}

Increased deposition and accumulation of $A \beta$ in the brain parenchyma and cerebral blood vessels and $A \beta$-altered cell membranes are the major physiologic events in AD. Here, we have reviewed the effects of $A \beta$ on neuronal cells, astrocytes, and CECs with the focus on cell membrane properties. Strong evidence has shown that $\mathrm{A} \beta$-membrane binding causes the disturbance of the biochemical, biophysical, and functional parameters of the plasma, intracellular, and mitochondria membranes. An alteration of membrane properties and changes of membrane-related protein activity in neurons and astrocytes can disrupt calcium metabolism and, by leading to mitochondria dysfunctions, can trigger downstream cellular pathways causing oxidative stress and neurodegeneration. In the brain endothelium, $A \beta$ interaction with endothelium increases ROS generation and apoptosis in the CECs induces inflammation and recruitment of immune cells from a bloodstream, enhances cell stiffness, and weakens adhesion between membranes and cytoskeleton.

On the other hand, membrane physical and chemical properties may influence APP processing, A $\beta$ binding, and permeabilization to membrane. Therefore, understanding different molecular mechanisms underlying $A \beta$-membrane interactions should provide new insights into the develop- 
ment of preventive and treatment strategies for cerebrovascular and neurodegenerative disorders.

Acknowledgements This work was supported by National Institutes of Health Grants 1P01AG18357, 1R21NS052385, and 1R21AG032579.

\section{References}

1. Frautschy SA, Yang F, Irrizarry M, Hyman B, Saido TC, Hsiao K, Cole GM (1998) Microglial response to amyloid plaques in APPsw transgenic mice. Am J Pathol 152:307-317

2. McGeer PL, Itagaki S, Tago H, McGeer EG (1987) Reactive microglia in patients with senile dementia of the Alzheimer type are positive for the histocompatibility glycoprotein HLA-DR. Neurosci Lett 79:195-200

3. Maat-Schieman ML, van Duinen SG, Rozemuller AJ, Haan J, Roos RA (1997) Association of vascular amyloid beta and cells of the mononuclear phagocyte system in hereditary cerebral hemorrhage with amyloidosis (Dutch) and Alzheimer disease. J Neuropathol Exp Neurol 56:273-284

4. Uchihara T, Akiyama H, Kondo H, Ikeda K (1997) Activated microglial cells are colocalized with perivascular deposits of amyloid-beta protein in Alzheimer's disease brain. Stroke 28:1948-1950

5. Dickson DW (1999) Microglia in Alzheimer's disease and transgenic models. How close the fit? Am J Pathol 154:16271631

6. Stalder M, Phinney A, Probst A, Sommer B, Staufenbiel M, Jucker M (1999) Association of microglia with amyloid plaques in brains of APP23 transgenic mice. Am J Pathol 154:16731684

7. Vassar R (2004) BACE1: the beta-secretase enzyme in Alzheimer's disease. J Mol Neurosci 23:105-114

8. Selkoe DJ (2000) The origins of Alzheimer disease: a is for amyloid. JAMA 283:1615-1617

9. Cleary JP, Walsh DM, Hofmeister JJ, Shankar GM, Kuskowski MA, Selkoe DJ, Ashe KH (2005) Natural oligomers of the amyloid-beta protein specifically disrupt cognitive function. Nat Neurosci 8:79-84

10. Mucke L, Masliah E, Yu GQ, Mallory M, Rockenstein EM, Tatsuno G, Hu K, Kholodenko D, Johnson-Wood K, McConlogue L (2000) High-level neuronal expression of abeta 1-42 in wildtype human amyloid protein precursor transgenic mice: synaptotoxicity without plaque formation. J Neurosci 20:4050-4058

11. Resende R, Ferreiro E, Pereira C, Resende de Oliveira C (2008) Neurotoxic effect of oligomeric and fibrillar species of amyloidbeta peptide 1-42: involvement of endoplasmic reticulum calcium release in oligomer-induced cell death. Neuroscience 155:725-737

12. Walsh DM, Klyubin I, Fadeeva JV, Rowan MJ, Selkoe DJ (2002) Amyloid-beta oligomers: their production, toxicity and therapeutic inhibition. Biochem Soc Trans 30:552-557

13. Westerman MA, Cooper-Blacketer D, Mariash A, Kotilinek L, Kawarabayashi T, Younkin LH, Carlson GA, Younkin SG, Ashe KH (2002) The relationship between Abeta and memory in the Tg2576 mouse model of Alzheimer's disease. J Neurosci 22:1858-1867

14. Hardy JA, Higgins GA (1992) Alzheimer's disease: the amyloid cascade hypothesis. Science 256:184-185

15. Hellstrom IC, Danik M, Luheshi GN, Williams S (2005) Chronic LPS exposure produces changes in intrinsic membrane properties and a sustained IL-beta-dependent increase in GABAergic inhibition in hippocampal CA1 pyramidal neurons. Hippocampus 15:656-664

16. Ditaranto K, Tekirian TL, Yang AJ (2001) Lysosomal membrane damage in soluble Abeta-mediated cell death in Alzheimer's disease. Neurobiol Dis 8:19-31

17. Klein J (2000) Membrane breakdown in acute and chronic neurodegeneration: focus on choline-containing phospholipids. J Neural Transm 107:1027-1063

18. Yao JK, Wengenack TM, Curran GL, Poduslo JF (2009) Reduced membrane lipids in the cortex of Alzheimer's disease transgenic mice. Neurochem Res 34:102-108

19. Simakova O, Arispe NJ (2007) The cell-selective neurotoxicity of the Alzheimer's Abeta peptide is determined by surface phosphatidylserine and cytosolic ATP levels. Membrane binding is required for Abeta toxicity. J Neurosci 27:13719-13729

20. Esposito C, Tedeschi A, Scrima M, D'Errico G, Ottaviani MF, Rovero P, D'Ursi AM (2006) Exploring interaction of betaamyloid segment (25-35) with membrane models through paramagnetic probes. J Pept Sci 12:766-774

21. Bokvist M, Lindstrom F, Watts A, Grobner G (2004) Two types of Alzheimer's beta-amyloid (1-40) peptide membrane interactions: aggregation preventing transmembrane anchoring versus accelerated surface fibril formation. J Mol Biol 335:10391049

22. Williamson R, Usardi A, Hanger DP, Anderton BH (2008) Membrane-bound beta-amyloid oligomers are recruited into lipid rafts by a fyn-dependent mechanism. FASEB J 22:15521559

23. Wahlstrom A, Hugonin L, Peralvarez-Marin A, Jarvet J, Graslund A (2008) Secondary structure conversions of Alzheimer's Abeta (1-40) peptide induced by membrane-mimicking detergents. FEBS J 275:5117-5128

24. Verdier Y, Zarandi M, Penke B (2004) Amyloid beta-peptide interactions with neuronal and glial cell plasma membrane: binding sites and implications for Alzheimer's disease. J Pept Sci 10:229-248

25. Verdier Y, Penke B (2004) Binding sites of amyloid beta-peptide in cell plasma membrane and implications for Alzheimer's disease. Curr Protein Pept Sci 5:19-31

26. Wong PT, Schauerte JA, Wisser KC, Ding H, Lee EL, Steel DG, Gafni A (2009) Amyloid-beta membrane binding and permeabilization are distinct processes influenced separately by membrane charge and fluidity. J Mol Biol 386:81-96

27. Blanchard BJ, Thomas VL, Ingram VM (2002) Mechanism of membrane depolarization caused by the Alzheimer Abeta1-42 peptide. Biochem Biophys Res Commun 293:1197-1203

28. Vaisid T, Kosower NS, Elkind E, Barnoy S (2008) Amyloid beta peptide toxicity in differentiated $\mathrm{PC} 12$ cells: calpaincalpastatin, caspase, and membrane damage. J Neurosci Res 86:2314-2325

29. Murray IV, Sindoni ME, Axelsen PH (2005) Promotion of oxidative lipid membrane damage by amyloid beta proteins. Biochemistry 44:12606-12613

30. Ditaranto-Desimone K, Saito M, Tekirian TL, Berg M, Dubowchik G, Soreghan B, Thomas S, Marks N, Yang AJ (2003) Neuronal endosomal/lysosomal membrane destabilization activates caspases and induces abnormal accumulation of the lipid secondary messenger ceramide. Brain Res Bull 59:523-531

31. Reid PC, Urano Y, Kodama T, Hamakubo T (2007) Alzheimer's disease: cholesterol, membrane rafts, isoprenoids and statins. J Cell Mol Med 11:383-392

32. Wood WG, Schroeder F, Igbavboa U, Avdulov NA, Chochina SV (2002) Brain membrane cholesterol domains, aging and amyloid beta-peptides. Neurobiol Aging 23:685-694 
33. Eckert GP, Kirsch C, Muller WE (2003) Brain-membrane cholesterol in Alzheimer's disease. J Nutr Health Aging 7:1823

34. Lynch C, Mobley W (2000) Comprehensive theory of Alzheimer's disease. The effects of cholesterol on membrane receptor trafficking. Ann N Y Acad Sci 924:104-111

35. Chochina SV, Avdulov NA, Igbavboa U, Cleary JP, O'Hare EO, Wood WG (2001) Amyloid beta-peptide1-40 increases neuronal membrane fluidity: role of cholesterol and brain region. J Lipid Res 42:1292-1297

36. Kojro E, Gimpl G, Lammich S, Marz W, Fahrenholz F (2001) Low cholesterol stimulates the nonamyloidogenic pathway by its effect on the alpha-secretase ADAM 10. Proc Natl Acad Sci U S A 98:5815-5820

37. Eckert GP, Kirsch C, Leutz S, Wood WG, Muller WE (2003) Cholesterol modulates amyloid beta-peptide's membrane interactions. Pharmacopsychiatry 36(Suppl 2):S136-S143

38. Ji SR, Wu Y, Sui SF (2002) Cholesterol is an important factor affecting the membrane insertion of beta-amyloid peptide (A beta 1-40), which may potentially inhibit the fibril formation. J Biol Chem 277:6273-6279

39. Abad-Rodriguez J, Ledesma MD, Craessaerts K, Perga S, Medina M, Delacourte A, Dingwall C, De Strooper B, Dotti CG (2004) Neuronal membrane cholesterol loss enhances amyloid peptide generation. J Cell Biol 167:953-960

40. Arispe N, Doh M (2002) Plasma membrane cholesterol controls the cytotoxicity of Alzheimer's disease AbetaP (1-40) and (1-42) peptides. FASEB J 16:1526-1536

41. Sponne I, Fifre A, Koziel V, Oster T, Olivier JL, Pillot T (2004) Membrane cholesterol interferes with neuronal apoptosis induced by soluble oligomers but not fibrils of amyloid-beta peptide. FASEB J 18:836-838

42. Lin MS, Chen LY, Wang SS, Chang Y, Chen WY (2008) Examining the levels of ganglioside and cholesterol in cell membrane on attenuation the cytotoxicity of beta-amyloid peptide. Colloids Surf B Biointerfaces 65:172-177

43. Nicholson AM, Ferreira A (2009) Increased membrane cholesterol might render mature hippocampal neurons more susceptible to beta-amyloid-induced calpain activation and tau toxicity. J Neurosci 29:4640-4651

44. Curtain CC, Ali FE, Smith DG, Bush AI, Masters CL, Barnham $\mathrm{KJ}$ (2003) Metal ions, $\mathrm{pH}$, and cholesterol regulate the interactions of Alzheimer's disease amyloid-beta peptide with membrane lipid. J Biol Chem 278:2977-2982

45. Stutzmann GE, Caccamo A, LaFerla FM, Parker I (2004) Dysregulated IP3 signaling in cortical neurons of knock-in mice expressing an Alzheimer's-linked mutation in presenilin1 results in exaggerated $\mathrm{Ca}^{2+}$ signals and altered membrane excitability. J Neurosci 24:508-513

46. Barbar E, Rola-Pleszczynski M, Payet MD, Dupuis G (2003) Protein kinase $\mathrm{C}$ inhibits the transplasma membrane influx of $\mathrm{Ca} 2+$ triggered by 4-aminopyridine in Jurkat $\mathrm{T}$ lymphocytes. Biochim Biophys Acta 1622:89-98

47. Qin Y, Qi JS, Qiao JT (2006) Apolipoprotein E4 suppresses delayed-rectifier potassium channels in membrane patches excised from hippocampal neurons. Synapse 59:82-91

48. Lin H, Zhu YJ, Lal R (1999) Amyloid beta protein (1-40) forms calcium-permeable, $\mathrm{Zn}^{2+}$-sensitive channel in reconstituted lipid vesicles. Biochemistry 38:11189-11196

49. Rhee SK, Quist AP, Lal R (1998) Amyloid beta protein-(1-42) forms calcium-permeable, $\mathrm{Zn}^{2+}$-sensitive channel. J Biol Chem 273:13379-13382

50. Ye C, Ho-Pao CL, Kanazirska M, Quinn S, Rogers K, Seidman CE, Seidman JG, Brown EM, Vassilev PM (1997) Amyloid-beta proteins activate $\mathrm{Ca}(2+)$-permeable channels through calciumsensing receptors. J Neurosci Res 47:547-554
51. Arispe N, Rojas E, Pollard HB (1993) Alzheimer disease amyloid beta protein forms calcium channels in bilayer membranes: blockade by tromethamine and aluminum. Proc Natl Acad Sci U S A 90:567-571

52. Sberna G, Saez-Valero J, Beyreuther K, Masters CL, Small DH (1997) The amyloid beta-protein of Alzheimer's disease increases acetylcholinesterase expression by increasing intracellular calcium in embryonal carcinoma P19 cells. J Neurochem 69:1177-1184

53. Abramov AY, Canevari L, Duchen MR (2004) Calcium signals induced by amyloid beta peptide and their consequences in neurons and astrocytes in culture. Biochim Biophys Acta 1742:81-87

54. Ho R, Ortiz D, Shea TB (2001) Amyloid-beta promotes calcium influx and neurodegeneration via stimulation of $\mathrm{L}$ voltagesensitive calcium channels rather than NMDA channels in cultured neurons. J Alzheimers Dis 3:479-483

55. Niu Y, Su Z, Zhao C, Song B, Zhang X, Zhao N, Shen X, Gong $Y$ (2009) Effect of amyloid beta on capacitive calcium entry in neural 2a cells. Brain Res Bull 78:152-157

56. Berrocal M, Marcos D, Sepulveda MR, Perez M, Avila J, Mata AM (2009) Altered $\mathrm{Ca}^{2+}$ dependence of synaptosomal plasma membrane $\mathrm{Ca}^{2+}$-ATPase in human brain affected by Alzheimer's disease. FASEB J 23:1826-1834

57. Koyama Y, Matsuzaki S, Gomi F, Yamada K, Katayama T, Sato K, Kumada T, Fukuda A, Matsuda S, Tano Y, Tohyama M (2008) Induction of amyloid beta accumulation by ER calcium disruption and resultant upregulation of angiogenic factors in ARPE19 cells. Invest Ophthalmol Vis Sci 49:2376-2383

58. Ferreiro E, Oliveira CR, Pereira CM (2008) The release of calcium from the endoplasmic reticulum induced by amyloidbeta and prion peptides activates the mitochondrial apoptotic pathway. Neurobiol Dis 30:331-342

59. Isaacs AM, Senn DB, Yuan M, Shine JP, Yankner BA (2006) Acceleration of amyloid beta-peptide aggregation by physiological concentrations of calcium. J Biol Chem 281:2791627923

60. Stephenson D, Rash K, Smalstig B, Roberts E, Johnstone E, Sharp J, Panetta J, Little S, Kramer R, Clemens J (1999) Cytosolic phospholipase A2 is induced in reactive glia following different forms of neurodegeneration. Glia 27:110-128

61. Stephenson DT, Lemere CA, Selkoe DJ, Clemens JA (1996) Cytosolic phospholipase A2 (cPLA2) immunoreactivity is elevated in Alzheimer's disease brain. Neurobiol Dis 3:51-63

62. Moses GS, Jensen MD, Lue LF, Walker DG, Sun AY, Simonyi A, Sun GY (2006) Secretory PLA2-IIA: a new inflammatory factor for Alzheimer's disease. J Neuroinflammation 3:28

63. Sun GY, Xu J, Jensen MD, Simonyi A (2004) Phospholipase A2 in the central nervous system: implications for neurodegenerative diseases. J Lipid Res 45:205-213

64. Murakami M, Kudo I (2002) Phospholipase A2. J Biochem 131:285-292

65. Muralikrishna Adibhatla R, Hatcher JF (2006) Phospholipase A2, reactive oxygen species, and lipid peroxidation in cerebral ischemia. Free Radic Biol Med 40:376-387

66. Sun GY, Horrocks LA, Farooqui AA (2007) The roles of NADPH oxidase and phospholipases A2 in oxidative and inflammatory responses in neurodegenerative diseases. J Neurochem 103:1-16

67. Farooqui AA, Ong WY, Horrocks LA (2006) Inhibitors of brain phospholipase A2 activity: their neuropharmacological effects and therapeutic importance for the treatment of neurologic disorders. Pharmacol Rev 58:591-620

68. Farooqui AA, Horrocks LA (2006) Phospholipase A2-generated lipid mediators in the brain: the good, the bad, and the ugly. Neuroscientist 12:245-260 
69. Yagami T (2006) Cerebral arachidonate cascade in dementia: Alzheimer's disease and vascular dementia. Curr Neuropharmacol 4:87-100

70. Yedgar S, Cohen Y, Shoseyov D (2006) Control of phospholipase A2 activities for the treatment of inflammatory conditions. Biochim Biophys Acta 1761:1373-1382

71. Dennis EA (1994) Diversity of group types, regulation, and function of phospholipase A2. J Biol Chem 269:1305713060

72. Sun GY, Xu J, Jensen MD, Yu S, Wood WG, Gonzalez FA, Simonyi A, Sun AY, Weisman GA (2005) Phospholipase A2 in astrocytes: responses to oxidative stress, inflammation, and $\mathrm{G}$ protein-coupled receptor agonists. Mol Neurobiol 31:27-41

73. Colangelo V, Schurr J, Ball MJ, Pelaez RP, Bazan NG, Lukiw WJ (2002) Gene expression profiling of 12633 genes in Alzheimer hippocampal CA1: transcription and neurotrophic factor down-regulation and up-regulation of apoptotic and proinflammatory signaling. J Neurosci Res 70:462-473

74. Bate C, Williams A (2007) Squalestatin protects neurons and reduces the activation of cytoplasmic phospholipase A2 by Abeta(1-42). Neuropharmacology 53:222-231

75. Kriem B, Sponne I, Fifre A, Malaplate-Armand C, Lozac'h-Pillot K, Koziel V, Yen-Potin FT, Bihain B, Oster T, Olivier JL, Pillot $\mathrm{T}$ (2005) Cytosolic phospholipase A2 mediates neuronal apoptosis induced by soluble oligomers of the amyloid-beta peptide. FASEB J 19:85-87

76. Chalimoniuk M, Stolecka A, Cakala M, Hauptmann S, Schulz K, Lipka U, Leuner K, Eckert A, Muller WE, Strosznajder JB (2007) Amyloid beta enhances cytosolic phospholipase A2 level and arachidonic acid release via nitric oxide in APP-transfected PC12 cells. Acta Biochim Pol 54:611-623

77. Shelat PB, Chalimoniuk M, Wang JH, Strosznajder JB, Lee JC, Sun AY, Simonyi A, Sun GY (2008) Amyloid beta peptide and NMDA induce ROS from NADPH oxidase and AA release from cytosolic phospholipase A2 in cortical neurons. J Neurochem 106:45-55

78. Hicks JB, Lai Y, Sheng W, Yang X, Zhu D, Sun GY, Lee JC (2008) Amyloid-beta peptide induces temporal membrane biphasic changes in astrocytes through cytosolic phospholipase A2. Biochim Biophys Acta 1778:2512-2519

79. Lingwood D, Simons K. Lipid rafts as a membrane-organizing principle. Science 327:46-50

80. Lingwood D, Kaiser HJ, Levental I, Simons K (2009) Lipid rafts as functional heterogeneity in cell membranes. Biochem Soc Trans 37:955-960

81. Parasassi T, De Stasio G, d'Ubaldo A, Gratton E (1990) Phase fluctuation in phospholipid membranes revealed by Laurdan fluorescence. Biophys J 57:1179-1186

82. Parasassi T, De Stasio G, Ravagnan G, Rusch RM, Gratton E (1991) Quantitation of lipid phases in phospholipid vesicles by the generalized polarization of Laurdan fluorescence. Biophys J 60:179-189

83. Parasassi T, Di Stefano M, Loiero M, Ravagnan G, Gratton E (1994) Influence of cholesterol on phospholipid bilayers phase domains as detected by Laurdan fluorescence. Biophys J 66:120-132

84. Parasassi T, Di Stefano M, Ravagnan G, Sapora O, Gratton E (1992) Membrane aging during cell growth ascertained by Laurdan generalized polarization. Exp Cell Res 202:432-439

85. Parasassi T, Ravagnan G, Rusch RM, Gratton E (1993) Modulation and dynamics of phase properties in phospholipid mixtures detected by Laurdan fluorescence. Photochem Photobiol 57:403-410

86. Waschuk SA, Elton EA, Darabie AA, Fraser PE, McLaurin JA (2001) Cellular membrane composition defines A beta-lipid interactions. J Biol Chem 276:33561-33568
87. Zhu D, Hu C, Sheng W, Tan KS, Haidekker MA, Sun AY, Sun GY, Lee JC (2009) NAD(P)H oxidase-mediated reactive oxygen species production alters astrocyte membrane molecular order via phospholipase A2. Biochem J 421:201-210

88. Eckert GP, Cairns NJ, Maras A, Gattaz WF, Muller WE (2000) Cholesterol modulates the membrane-disordering effects of beta-amyloid peptides in the hippocampus: specific changes in Alzheimer's disease. Dement Geriatr Cogn Disord $11: 181-186$

89. Gattaz WF, Maras A, Cairns NJ, Levy R, Forstl H (1995) Decreased phospholipase A2 activity in Alzheimer brains. Biol Psychiatry 37:13-17

90. Ross BM, Moszczynska A, Erlich J, Kish SJ (1998) Phospholipid-metabolizing enzymes in Alzheimer's disease: increased lysophospholipid acyltransferase activity and decreased phospholipase A2 activity. J Neurochem 70:786-793

91. Forlenza OV, Schaeffer EL, Gattaz WF (2007) The role of phospholipase A2 in neuronal homeostasis and memory formation: implications for the pathogenesis of Alzheimer's disease. $\mathrm{J}$ Neural Transm 114:231-238

92. Schaeffer EL, Bassi F Jr, Gattaz WF (2005) Inhibition of phospholipase A2 activity reduces membrane fluidity in rat hippocampus. J Neural Transm 112:641-647

93. Reddy PH, Beal MF (2008) Amyloid beta, mitochondrial dysfunction and synaptic damage: implications for cognitive decline in aging and Alzheimer's disease. Trends Mol Med $14: 45-53$

94. Manczak M, Park BS, Jung Y, Reddy PH (2004) Differential expression of oxidative phosphorylation genes in patients with Alzheimer's disease: implications for early mitochondrial dysfunction and oxidative damage. Neuromolecular Med 5:147-162

95. Reddy PH, McWeeney S, Park BS, Manczak M, Gutala RV, Partovi D, Jung Y, Yau V, Searles R, Mori M, Quinn J (2004) Gene expression profiles of transcripts in amyloid precursor protein transgenic mice: up-regulation of mitochondrial metabolism and apoptotic genes is an early cellular change in Alzheimer's disease. Hum Mol Genet 13:1225-1240

96. Devi L, Prabhu BM, Galati DF, Avadhani NG, Anandatheerthavarada HK (2006) Accumulation of amyloid precursor protein in the mitochondrial import channels of human Alzheimer's disease brain is associated with mitochondrial dysfunction. J Neurosci 26:9057-9068

97. Sultana R, Perluigi M, Butterfield DA (2006) Protein oxidation and lipid peroxidation in brain of subjects with Alzheimer's disease: insights into mechanism of neurodegeneration from redox proteomics. Antioxid Redox Signal 8:2021-2037

98. Wang J, Xiong S, Xie C, Markesbery WR, Lovell MA (2005) Increased oxidative damage in nuclear and mitochondrial DNA in Alzheimer's disease. J Neurochem 93:953-962

99. Zhu X, Smith MA, Perry G, Aliev G (2004) Mitochondrial failures in Alzheimer's disease. Am J Alzheimers Dis Other Demen 19:345-352

100. Caspersen C, Wang N, Yao J, Sosunov A, Chen X, Lustbader JW, Xu HW, Stern D, McKhann G, Yan SD (2005) Mitochondrial Abeta: a potential focal point for neuronal metabolic dysfunction in Alzheimer's disease. FASEB J 19:2040-2041

101. Du H, Guo L, Fang F, Chen D, Sosunov AA, McKhann GM, Yan Y, Wang C, Zhang H, Molkentin JD, Gunn-Moore FJ, Vonsattel JP, Arancio O, Chen JX, Yan SD (2008) Cyclophilin D deficiency attenuates mitochondrial and neuronal perturbation and ameliorates learning and memory in Alzheimer's disease. Nat Med 14:1097-1105

102. Hansson Petersen CA, Alikhani N, Behbahani H, Wiehager B, Pavlov PF, Alafuzoff I, Leinonen V, Ito A, Winblad B, Glaser E, Ankarcrona M (2008) The amyloid beta-peptide is imported into mitochondria via the TOM import machinery and localized to 
mitochondrial cristae. Proc Natl Acad Sci U S A 105:1314513150

103. Manczak M, Anekonda TS, Henson E, Park BS, Quinn J, Reddy PH (2006) Mitochondria are a direct site of A beta accumulation in Alzheimer's disease neurons: implications for free radical generation and oxidative damage in disease progression. Hum Mol Genet 15:1437-1449

104. Wang X, Su B, Siedlak SL, Moreira PI, Fujioka H, Wang Y, Casadesus G, Zhu X (2008) Amyloid-beta overproduction causes abnormal mitochondrial dynamics via differential modulation of mitochondrial fission/fusion proteins. Proc Natl Acad Sci U S A 105:19318-19323

105. Zhu D, Lai Y, Shelat PB, Hu C, Sun GY, Lee JC (2006) Phospholipases A2 mediate amyloid-beta peptide-induced mitochondrial dysfunction. J Neurosci 26:11111-11119

106. Di Paola M, Lorusso M (2006) Interaction of free fatty acids with mitochondria: coupling, uncoupling and permeability transition. Biochim Biophys Acta 1757:1330-1337

107. Hirabara SM, Silveira LR, Alberici LC, Leandro CV, Lambertucci RH, Polimeno GC, Cury Boaventura MF, Procopio J, Vercesi AE, Curi R (2006) Acute effect of fatty acids on metabolism and mitochondrial coupling in skeletal muscle. Biochim Biophys Acta 1757:57-66

108. Penzo D, Petronilli V, Angelin A, Cusan C, Colonna R, Scorrano L, Pagano F, Prato M, Di Lisa F, Bernardi P (2004) Arachidonic acid released by phospholipase $\mathrm{A}(2)$ activation triggers $\mathrm{Ca}(2+)$ dependent apoptosis through the mitochondrial pathway. J Biol Chem 279:25219-25225

109. Thornton E, Vink R, Blumbergs PC, Van Den Heuvel C (2006) Soluble amyloid precursor protein alpha reduces neuronal injury and improves functional outcome following diffuse traumatic brain injury in rats. Brain Res 1094:38-46

110. Haass C, Hung AY, Schlossmacher MG, Teplow DB, Selkoe DJ (1993) Beta-Amyloid peptide and a 3-kDa fragment are derived by distinct cellular mechanisms. J Biol Chem 268:3021-3024

111. Koo EH, Squazzo SL (1994) Evidence that production and release of amyloid beta-protein involves the endocytic pathway. $\mathrm{J}$ Biol Chem 269:17386-17389

112. Cordy JM, Hussain I, Dingwall C, Hooper NM, Turner AJ (2003) Exclusively targeting beta-secretase to lipid rafts by GPIanchor addition up-regulates beta-site processing of the amyloid precursor protein. Proc Natl Acad Sci U S A 100:11735-11740

113. Ehehalt R, Keller P, Haass C, Thiele C, Simons K (2003) Amyloidogenic processing of the Alzheimer beta-amyloid precursor protein depends on lipid rafts. J Cell Biol 160:113-123

114. Kaether C, Haass C (2004) A lipid boundary separates APP and secretases and limits amyloid beta-peptide generation. J Cell Biol 167:809-812

115. Marlow L, Cain M, Pappolla MA, Sambamurti K (2003) Betasecretase processing of the Alzheimer's amyloid protein precursor (APP). J Mol Neurosci 20:233-239

116. Tun H, Marlow L, Pinnix I, Kinsey R, Sambamurti K (2002) Lipid rafts play an important role in A beta biogenesis by regulating the beta-secretase pathway. J Mol Neurosci 19:31-35

117. Vetrivel KS, Cheng H, Lin W, Sakurai T, Li T, Nukina N, Wong PC, Xu H, Thinakaran G (2004) Association of gamma-secretase with lipid rafts in post-Golgi and endosome membranes. J Biol Chem 279:44945-44954

118. Sawamura N, Ko M, Yu W, Zou K, Hanada K, Suzuki T, Gong JS, Yanagisawa K, Michikawa M (2004) Modulation of amyloid precursor protein cleavage by cellular sphingolipids. J Biol Chem 279:11984-11991

119. Simons M, Keller P, De Strooper B, Beyreuther K, Dotti CG, Simons K (1998) Cholesterol depletion inhibits the generation of beta-amyloid in hippocampal neurons. Proc Natl Acad Sci U S A 95:6460-6464
120. von Arnim CA, von Einem B, Weber P, Wagner M, Schwanzar D, Spoelgen R, Strauss WL, Schneckenburger H (2008) Impact of cholesterol level upon APP and BACE proximity and APP cleavage. Biochem Biophys Res Commun 370:207-212

121. Cho HW, Kim JH, Choi S, Kim HJ (2006) Phospholipase A2 is involved in muscarinic receptor-mediated sAPPalpha release independently of cyclooxygenase or lypoxygenase activity in SH-SY5Y cells. Neurosci Lett 397:214-218

122. Yang X, Sheng W, He Y, Cui J, Haidekker MA, Sun GY, Lee JC (2009) Secretory phospholipase A2 Type III enhances \{alpha\}secretase-dependent amyloid precursor protein processing through alterations in membrane fluidity. J Lipid Res

123. Fukaya T, Gondaira T, Kashiyae Y, Kotani S, Ishikura Y, Fujikawa S, Kiso Y, Sakakibara M (2007) Arachidonic acid preserves hippocampal neuron membrane fluidity in senescent rats. Neurobiol Aging 28:1179-1186

124. Kogel D, Copanaki E, Hartig U, Bottner S, Peters I, Muller WE, Eckert G (2008) Modulation of membrane fluidity by omega 3 fatty acids: enhanced generation of sAPPalpha is required for the neuroprotective effects of DHA. The 38th annual meeting of the Society for Neuroscience. Washington, DC., Nov 15-19, 2008

125. Peters I, Igbavboa U, Schutt T, Haidari S, Hartig U, Rosello X, Bottner S, Copanaki E, Deller T, Kogel D, Wood WG, Muller WE, Eckert GP (2009) The interaction of beta-amyloid protein with cellular membranes stimulates its own production. Biochim Biophys Acta 1788:964-972

126. Cirrito JR, Kang JE, Lee J, Stewart FR, Verges DK, Silverio LM, $\mathrm{Bu}$ G, Mennerick S, Holtzman DM (2008) Endocytosis is required for synaptic activity-dependent release of amyloid-beta in vivo. Neuron 58:42-51

127. Kinoshita A, Fukumoto H, Shah T, Whelan CM, Irizarry MC, Hyman BT (2003) Demonstration by FRET of BACE interaction with the amyloid precursor protein at the cell surface and in early endosomes. J Cell Sci 116:3339-3346

128. Rajendran L, Schneider A, Schlechtingen G, Weidlich S, Ries J, Braxmeier T, Schwille P, Schulz JB, Schroeder C, Simons M, Jennings G, Knolker H-J, Simons K (2008) Efficient Inhibition of the Alzheimer's Disease \{beta\}-Secretase by Membrane Targeting. Science 320:520-523

129. Schobel S, Neumann S, Hertweck M, Dislich B, Kuhn PH, Kremmer E, Seed B, Baumeister R, Haass C, Lichtenthaler SF (2008) A novel sorting nexin modulates endocytic trafficking and alpha-secretase cleavage of the amyloid precursor protein. $\mathrm{J}$ Biol Chem 283:14257-14268

130. Small SA, Gandy S (2006) Sorting through the cell biology of Alzheimer's disease: intracellular pathways to pathogenesis. Neuron 52:15-31

131. Luc B, Patrick R HOF, Andre D (1997) Brain microvascular changes in Alzheimer's disease and other dementias. Ann N Y Acad Sci 826:7-24

132. Berzin TM, Zipser BD, Rafii MS, Kuo-Leblanc V, Yancopoulos GD, Glass DJ, Fallon JR, Stopa EG (2000) Agrin and microvascular damage in Alzheimer's disease. Neurobiol Aging 21:349-355

133. Bailey TL, Rivara CB, Rocher AB, Hof PR (2004) The nature and effects of cortical microvascular pathology in aging and Alzheimer's disease. Neurol Res 26:573-578

134. Kalaria RN, Pax AB (1995) Increased collagen content of cerebral microvessels in Alzheimer's disease. Brain Res 705:349-352

135. Ervin JF, Pannell C, Szymanski M, Welsh-Bohmer K, Schmechel DE, Hulette CM (2004) Vascular Smooth muscle actin is reduced in Alzheimer disease brain: a quantitative analysis. J Neuropathol Exp Neurol 63:735-741

136. Kalaria RN, P H (1995) Differential degeneration of the cerebral microvasculature in Alzheimer's disease. Neuroreport 6:477-480 
137. Claudio L (1996) Ultrastructural features of the blood-brain barrier in biopsy tissue from Alzheimer's disease patients. Acta Neuropathol 91:6-14

138. Aliev G, Seyidova D, Lamb BT, Obrenovich ME, Siedlak SL, Vinters HV, Friedland RP, Lamanna JC, Smith MA, Perry G (2003) Mitochondria and vascular lesions as a central target for the development of Alzheimer's disease and Alzheimer disease-like pathology in transgenic mice. Neurol Res 25:665674

139. De la Torre JC (2004) Is Alzheimer's disease a neurodegenerative or a vascular disorder? Data, dogma, and dialectics. The Lancet Neurology 3:184-190

140. Price JM, Chi X, Hellermann G, Sutton ET (2001) Physiological levels of beta-amyloid induce cerebral vessel dysfunction and reduce endothelial nitric oxide production. Neurol Res 23:506-512

141. Emmanuelle MB, Michal T, Robert JM, Bernhard H (1997) Amyloid $\beta$-peptide induces cell monolayer albumin permeability, impairs glucose transport, and induces apoptosis in vascular endothelial cells. J Neurochem 68:1870-1881

142. Bhatia R, Lin HAI, Lal R (2000) Fresh and globular amyloid betaprotein (1-42) induces rapid cellular degeneration: evidence for A \{beta\}P channel-mediated cellular toxicity. FASEB J 14:1233-1243

143. Xu J, Chen S, Ku G, Ahmed SH, Xu J, Chen H, Hsu CY (2001) Amyloid beta-peptide-induced cerebral endothelial cell death involves mitochondrial dysfunction and caspase activation. J Cereb Blood Flow Metab 21:702-710

144. Park LAJ, Forster C, Kazama K, Carlson GA, Iadecola C (2004) Abeta-induced vascular oxidative stress and attenuation of functional hyperemia in mouse somatosensory cortex. Journal of Cerebral Blood Flow Metabolism 24:334-342

145. Iadecola CZF, Niwa K, Eckman C, Turner SK, Fischer E, Younkin S, Borchelt DR, Hsiao KK, Carlson GA (1999) SOD1 rescues cerebral endothelial dysfunction in mice overexpressing amyloid precursor protein. Nat Neurosci 2:157-161

146. Tong X-K, Nicolakakis N, Kocharyan A, Hamel E (2005) Vascular remodeling versus amyloid-beta-induced oxidative stress in the cerebrovascular dysfunctions associated with Alzheimer's disease. J Neurosci 25:11165-11174

147. Yin KJ, Lee JM, Chen SD, Xu J, Hsu CY (2002) Amyloid-beta induces Smac release via AP-1/Bim activation in cerebral endothelial cells. J Neurosci 22:9764-9770

148. Hsu M-J, Hsu CY, Chen B-C, Chen M-C, Ou G, Lin C-H (2007) Apoptosis signal-regulating kinase 1 in amyloid-beta-peptideinduced cerebral endothelial cell apoptosis. J Neurosci 27:57195729

149. Grammas P, Ovase R (2001) Inflammatory factors are elevated in brain microvessels in Alzheimer's disease. Neurobiol Aging $22: 837-842$

150. Vukic V, Callaghan D, Walker D, Lue L-F, Liu QY, Couraud P-O, Romero IA, Weksler B, Stanimirovic DB, Zhang W (2009) Expression of inflammatory genes induced by beta-amyloid peptides in human brain endothelial cells and in Alzheimer's brain is mediated by the JNK-AP1 signaling pathway. Neurobiol Dis 34:95-106

151. Callaghan D, Bai J, Huang A, Vukic V, Xiong H, Jones A, Walker D, Leu LF, Beach TG, Sue L, Zhang W (2008) P4-182: inhibition of ABCG2 transport function by amyloid-beta peptide augments cellular oxidative stress and inflammatory gene expression in cells. Alzheimer's and Dementia 4:T724-T724

152. Park L, Anrather J, Zhou P, Frys K, Pitstick R, Younkin S, Carlson GA, Iadecola C (2005) NADPH oxidase-derived reactive oxygen species mediate the cerebrovascular dysfunction induced by the amyloid-beta-peptide. J Neurosci 25:1769-1777

153. Park L, Zhou P, Pitstick R, Capone C, Anrather J, Norris EH, Younkin L, Younkin S, Carlson G, McEwen BS, Iadecola C (2008) Nox2-derived radicals contribute to neurovascular and behavioral dysfunction in mice overexpressing the amyloid precursor protein. Proc Natl Acad Sci 105:1347-1352

154. Girouard H, Iadecola C (2006) Neurovascular coupling in the normal brain and in hypertension, stroke, and Alzheimer disease. J Appl Physiol 100:328-335

155. Maat-Schieman ML vDS, Rozemuller AJ, Haan J, Roos RA (1997) Association of vascular amyloid beta and cells of the mononuclear phagocyte system in hereditary cerebral hemorrhage with amyloidosis (Dutch) and Alzheimer disease. J Neuropathol Exp Neurol 56:273-284

156. Uchihara TAH, Kondo H, Ikeda K (1997) Activated microglial cells are colocalized with perivascular deposits of amyloid-beta protein in Alzheimer's disease brain. Stroke 28:1948-1950

157. Selkoe DJ, Schenk D (2003) Alzheimer's disease: molecular understanding predicts amyloid-based therapeutics. Annu Rev Pharmacol Toxicol 43:545-584

158. Mezey E, Chandross KJ, Harta G, Maki RA, McKercher SR (2000) Turning blood into brain: cells bearing neuronal antigens generated in vivo from bone marrow. Science 290:1779-1782

159. Giri R, Selvaraj S, Miller CA, Hofman F, Yan SD, Stern D, Zlokovic BV, Kalra VK (2002) Effect of endothelial cell polarity on beta-amyloid-induced migration of monocytes across normal and AD endothelium. Am J Physiol Cell Physiol 283:C895-C904

160. Francisco J. G-V, Melissa A. Moss (2008) Soluble aggregates of the amyloid- $\beta$ protein activate endothelial monolayers for adhesion and subsequent transmigration of monocyte cells. J Neurochem 104:500-513

161. Giri R, Shen Y, Stins M, Du Yan S, Schmidt AM, Stern D, Kim KS, Zlokovic B, Kalra VK (2000) Beta-amyloid-induced migration of monocytes across human brain endothelial cells involves RAGE and PECAM-1. Am J Physiol Cell Physiol 279: C1772-C1781

162. Reyes Barcelo A, Gonzalez-Velasquez F, Moss M (2009) Soluble aggregates of the amyloid-beta peptide are trapped by serum albumin to enhance amyloid-beta activation of endothelial cells. Journal of Biological Engineering 3:5

163. Frijns CJ, Kappelle LJ (2002) Inflammatory cell adhesion molecules in ischemic cerebrovascular disease. Stroke 33:2115-2122

164. Alon R, Chen S, Puri KD, Finger EB, Springer TA (1997) The kinetics of L-selectin tethers and the mechanics of selectinmediated rolling. J Cell Biol 138:1169-1180

165. Alon R, Hammer DA, Springer TA (1995) Lifetime of the P-selectincarbohydrate bond and its response to tensile force in hydrodynamic flow. Nature 374:539-542

166. Dembo M, Torney DC, Saxman K, Hammer D (1988) The reaction-limited kinetics of membrane-to-surface adhesion and detachment. Proc R Soc Lond B Biol Sci 234:55-83

167. Trache A, Trzeciakowski JP, Gardiner L, Sun Z, Muthuchamy M, Guo M, Yuan SY, Meininger GA (2005) Histamine effects on endothelial cell fibronectin interaction studied by atomic force microscopy. Biophys J 89:2888-2898

168. Sun M, Northup N, Marga F, Huber T, Byfield FJ, Levitan I, Forgacs G (2007) The effect of cellular cholesterol on membrane-cytoskeleton adhesion. J Cell Sci 120:2223-2231

169. Sun M, Graham JS, Hegedbs B, Marga F, Zhang Y, Forgacs G, Grandbois M (2005) Multiple membrane tethers probed by atomic force microscopy. Biophys J 89:4320-4329

170. Girdhar G, Shao J-Y (2004) Membrane tether extraction from human umbilical vein endothelial cells and its implication in leukocyte rolling. Biophys J 87:3561-3568

171. Girdhar G, Chen Y, Shao J-Y (2007) Double-tether extraction from human umbilical vein and dermal microvascular endothelial cells. Biophys J 92:1035-1045

172. Marco S, Skaper SD (2006) Amyloid [beta]-peptide ${ }_{1-42}$ alters tight junction protein distribution and expression in brain microvessel endothelial cells. Neurosci Lett 401:219-224 
173. Mendoza-Naranjo A, Gonzalez-Billault C, Maccioni RB (2007)

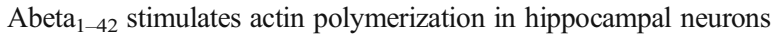
through Rac1 and Cdc42 Rho GTPases. J Cell Sci 120:279-288

174. Cheng S, George P, Dechun W, Ya Fang L (2002) Beta-Amyloid peptide induces formation of actin stress fibers through p38 mitogen-activated protein kinase. J Neurochem 83:828-836
175. Bell R, Zlokovic B (2009) Neurovascular mechanisms and blood-brain barrier disorder in Alzheimer's disease. Acta Neuropathol 118:103-113

176. Zlokovic BV (2008) New therapeutic targets in the neurovascular pathway in Alzheimer's disease. Neurotherapeutics $5: 409-414$ 